To be cited as:

Durand J.-D., Chen W.-J., Shen K.-N., Fu C., Borsa P. (2012) Genus-level taxonomic changes implied by the mitochondrial phylogeny of grey mullets (Teleostei: Mugilidae). C. R. Biol. 335, 687-697.

\title{
Genus-level taxonomic changes implied by the mitochondrial phylogeny of grey mullets
} (Teleostei: Mugilidae)

Révision des genres chez les mulets (Teleostei: Mugilidae), consécutive à la phylogénie mitochondriale des espèces de la famille

Jean-Dominique Durand a*, Wei-Jen Chen b, Kang-Ning Shen c, Cuizhang Fu d, Philippe Borsa ${ }^{\mathrm{e}}$

a Institut de recherche pour le développement (IRD), UMR5119 ECOSYM, Bat.24 Cc.093, Université Montpellier 2, Place E.

Bataillon 34095 Montpellier cedex 5, France

b Institute of Oceanography, National Taiwan University, No.1 Sec. 4 Roosevelt Rd. Taipei 10617, Taiwan

c Institute of Fisheries Science, National Taiwan University, Taipei 10617, Taiwan

d Institute of Biodiversity Science, Fudan University, Handan Road 220, Shanghai 200433, China

e IRD, UR 227 CoReUs, Montpellier, France

* Corresponding author: email: jean-dominique.durand@ird.fr; Tel:+33 46714 4571; Fax: + 33467143719 


\section{ABSTRACT}

A comprehensive mitochondrial phylogeny of the family Mugilidae (Durand et al., Mol. Phylogenet. Evol. 64 (2012) 73-92 [1]) demonstrated the polyphyly or paraphyly of a proportion of the 20 genera in the family. Based on these results, here we propose a revised classification with 25 genera, including 15 genera currently recognized as valid (Agonostomus, Aldrichetta, Cestraeus, Chaenomugil, Chelon, Crenimugil, Ellochelon, Joturus, Mugil, Myxus, Neomyxus, Oedalecbilus, Rhinomugil, Sicamugil and Trachystoma), 7 resurrected genera [Dajaus (for Agonostomus monticola), Gracilimugil (for Liza argentea), Minimugil (for Sicamugil cascasia), Osteomugil (for several species currently under Moolgarda and Valamugil, including M. cunnesius, M. engeli, M. perusii, and V. robustus), Planiliza (for Indo-Pacific Chelon spp., Indo-Pacific Liza spp., and Paramugil parmatus), Plicomugil (for Oedalechilus labiosus), and Squalomugil (for Rbinomugil nasutus)] and 3 new genera: Neochelon gen. nov. (for Liza falcipinnis), Parachelon gen. nov. (for L. grandisquamis) and Pseudomyxus gen. nov. (for Myxus capensis). Genus Chelon was shown to include exclusively Chelon spp. and Liza spp. from the Atlantic and the Mediterranean, and Liza spp. species endemic to eastern southern Africa. Genus Crenimugil should now include C. crenilabis, Moolgarda seheli and V. buchanani. Genus names Liza, Moolgarda, Paramugil, Valamugil and Xenomugil should be abandoned because they are no longer valid. Further genetic evidence is required to confirm or infirm the validity of the genus Paracrenimugil Senou 1988. The mitochondrial phylogeny of the 25 genera from the present revision is the following: [(Sicamugil, (Minimugil, Rbinomugi $)$ ); Trachystoma; ((Myxus, Neomyxus), (Cestraeus, Chaenomugil, (Agonostomus, Dajaus, Joturus), Mugi )); (Aldrichetta, Gracilimugil); Neochelon gen. nov.; (Pseudomyxus gen. nov., (Chelon, Oedalechilus, Planiliza, Parachelon gen. nov.)); ((Squalomugil, (Ellochelon, Plicomugi $)$ ), (Crenimugil, Osteomugi $))]$. Agonostomus monticola and several species with large distribution ranges (including Moolgarda seheli, Mugil cephalus and M. curema) consist of separate lineages whose geographic distribution suggests they are cryptic species, thus warranting further taxonomic work in the Mugilidae at the infra-generic level.

Keywords: paraphyly; polyphyly; taxonomy; systematics; nomenclature.

\section{RESUME}

Une phylogénie mitochondriale complète des Mugilidae (Durand et al., Mol. Phylogenet. Evol. 64 (2012) 73-92 [1]) a démontré la polyphylie ou la paraphylie d'une partie des 20 genres de cette famille. D'après ces résultats, nous proposons ici une classification révisée avec 25 genres, qui comprend 15 genres actuellement reconnus comme valides (Agonostomus, Aldrichetta, Cestraeus, Chaenomugil, Chelon, Crenimugil, Ellochelon, Joturus, Mugil, Myxus, Neomyxus, Oedalechilus, Rhinomugil, Sicamugil et Trachystoma), 7 genres réhabilités [Dajaus (pour Agonostomus monticola), Gracilimugil (pour Liza argentea), Minimugil (pour Sicamugil cascasia), Osteomugil (pour plusieurs espèces des genres Moolgarda et Valamugil, dont M. cunnesius, M. engeli, $M$. perusii et $V$. robustus), Planiliza (pour les espèces indo-pacifiques des genres Chelon et Liza ainsi que Paramugil parmatus), Plicomugil (pour Oedalechilus labiosus) et Squalomugil (pour Rbinomugil nasutus)] et 3 nouveaux genres : Neochelon gen. nov. (pour Liza falcipinnis), Parachelon gen. nov. (pour L. grandisquamis) et Pseudomyxus gen. nov. (pour Myxus capensis). Nous proposons que le genre Chelon comprenne désormais $C$. labrosus et tous les Liza spp. de l'Atlantique et de la Méditerranée ainsi que les Liža spp. endémiques de l'Afrique du Sud. Le genre Crenimugil doit désormais inclure C. crenilabis, Moolgarda seheli et V. buchanani. Les noms de genres Liza, Moolgarda, Paramugil, V alamugil et Xenomugil, non valides, doivent être abandonnés. Des analyses génétiques supplémentaires sont requises pour confirmer ou infirmer la validité du genre Paracrenimugil Senou 1988. La phylogénie mitochondriale des 25 genres ainsi proposés est la suivante: 
[(Sicamugil, (Minimugil, Rhinomugi $))$; Trachystoma ; ((Myxus, Neomyxus), (Cestraeus, Chaenomugil, (Agonostomus, Dajaus, Joturus), Mugil)) ; (Aldrichetta, Gracilimugi) ; Neochelon gen. nov.; (Pseudomyxus gen. nov. (Chelon, Oedalechilus, Planiliza, Parachelon gen. nov.)) ; ((Squalomugil, (Ellochelon, Plicomugi $))$, (Crenimugil, Osteomugi $))]$. Agonostomus monticola et plusieurs espèces à large distribution géographique (y compris les espèces Moolgarda seheli, Mugil cephalus et $M$. curema) se composent de lignées distinctes dont la répartition géographique suggère l'existence d'espèces cryptiques, justifiant ainsi de nouvelles recherches sur la taxonomie des Mugilidae au niveau infra-générique.

Mots clés : paraphylie; polyphylie; taxinomie; systématique; nomenclature.

\section{Introduction}

The potential input of molecular phylogenies to modern taxonomy is considerable [2-5], to the extent that a DNA-based approach to taxonomy is being envisaged [6-8]. It is arguable that molecular phylogenies should provide the basis to taxonomy in the cases where conflicts or uncertainty persist from classifications based on morphology, morpho-anatomy, and other phenotypic characters. Unlike molecular phylogenies, traditional taxonomy based on morphological characters can for instance be misled by phenotypic plasticity, morphological convergence, and arbitrary character weighting [8,9].

In the last 130 years, up to 281 nominal species and 43 nominal genera (Table 1) have been proposed for the Mugilidae [11]. The first thorough taxonomic revision of the Mugilidae was produced by Schultz [38], who mainly used mouth anatomy to define species and genera. Schultz [38] validated only ten previously defined mugilid genera and described three new ones, a revision that was subsequently questioned (review in [43]). The taxonomy and nomenclature of Mugilidae have still not been finalized [44], with between 14 and 20 genera being recognized as valid according to the most recent revisions [11, 12, 45]. The Integrated Taxonomic Information System (http://www.itis.gov/; information retrieved on 16 August 2011) recognizes 16 valid genera, while Eschmeyer and Fricke [13] list 20 valid genera. Two genera, Liza and Mugil, currently represent $40 \%$ of the species richness of the family Mugilidae [13]. While the taxonomy and nomenclature of species in the genus Mugil are mostly stable, those in the genus Liza have undergone changes since [38] (Table 1), reflecting disagreement among authors regarding the taxonomic placement of some of the species currently under this genus.

Molecular phylogenetic investigations of the Mugilidae have been mostly regional in scope, with a majority of studies concerning mugilid species sampled from the Mediterranean region, and a few other studies concerned with species from the Atlantic waters of South America, or from India, or from eastern Asia (reviewed in [1]). More recent studies have attempted to expand taxonomic sampling by including species and genera from various locations worldwide in addition to their initial treatment of Mediterranean Mugilidae [46, 47]. The most comprehensive phylogenetic survey of Mugilidae published thus far concerned 55 species representing 19 of the 20 currently recognized genera [1](Fig. 1). A substantial proportion of the species in particularly speciose genera Chelon (5/7 of currently recognized species), Liza (14/19), Mugil (9/12), Moolgarda (4/5) and Valamugil (3/4) were included. Broad geographic sampling was undertaken for the ubiquitous genera Chelon, Liza, and Mugil. Emphasis was also put on sampling several widely-distributed species of these and other genera, including C. macrolepis, Crenimugil crenilabis, Moolgarda cunnesius, M. seheli, Mugil cephalus, M. curema and Valamugil buchanani.

Durand et al.'s [1] phylogeny allowed to test previous phylogenetic hypotheses based on morphology and morphoanatomy, themselves in contradiction with one another (Figs. 1A-E of [1]). It was found that several genera in the Mugilidae actually were polyphyletic or paraphyletic with other genera and that the 
molecular phylogeny matches no one of the previous, morphology-based classifications. Here, we propose a revised classification based on these results.

\section{Methods}

We thus examined the phylogenetic placement of each of the 19 mugilid genera in the mitochondrial phylogeny of Mugilidae produced by [1] (Fig. 1). In addition, we determined the phylogenetic placement of the genus Xenomugil (represented by its single species X. thoburni).

A partial phylogeny of Mugilidae based on all available nucleotide sequences of a 300-bp fragment of the cytochrome $b(c y t b)$ gene had initially shown X. thoburni haplotypes to be embedded within the Mugil curema lineage (Appendix A). Consequently, here we run a new phylogenetic treatment of the genera Mugil and Xenomugil, using a new matrix of sequences that comprised representatives from all Mugil spp. lineages of [1], the new sequences of two X. thoburni individuals, and the additional sequences of two M. cephalus individuals from the Galapagos Islands. Both X. thoburni and additional M. cephalus from the Galapagos Islands were collected at Bahia Divine, Isla Santa Cruz on 15 June 2011 by T. Ballesteros. Their partial nucleotide sequences at the $16 \mathrm{~S} r \mathrm{RN} A$, cytochrome-oxidase I (COI) and cytb loci [GENBANK (http:/ /www.ncbi.nlm.nih.gov) accession numbers JX559523 to JX559535] were obtained using the same experimental protocols as [1].

For the present revision, a genus name was conserved if the topology of the tree supported the monophyly of the genus. When a genus currently considered valid was paraphyletic or polyphyletic, we split it into the minimum necessary number of genera according to the topology of the tree. The current genus name was conserved for the type species (Table 1) and, when applicable, its sister species in the same genus. For the other monophyletic groups under the same genus, former genus names were resurrected whenever applicable. For this, we considered the history of genus nomenclature in Mugilidae and the validity of the 43 genera proposed thus far (Table 1). The principle of priority [52] was followed when a previously proposed genus name was available. When no genus name was available for a given lineage, we proposed a new genus name.

Thus, our concern was to minimize disruption to the existing nomenclature. This accords with the principles of the PhyloCode [53].

\section{Results and Discussion}

A summary of Durand et al.'s [1] phylogenetic results (Fig. 1) and their taxonomic implications at the genus level are examined in the following. We added information on the distribution of each genus. Genera are listed in alphabetical order.

\subsection{Agonostomus}

Agonostomus was paraphyletic with respect to Joturus; $A$. monticola was phylogenetically closer to $J$. pichardi than both were from $A$. catalai (Fig. 1). At locus $16 S$, the nucleotide divergence between $A$. monticola (GENBANK JQ060644- JQ060652) and $A$. catalai (GENBANK JQ060643) was 13.3-13.5\% (Kimura 2-parameter; MEGA 5 [50]) while the estimated divergence between A. telfairii (GENBANK DQ532834) and $A$. catalai was $0.2 \%$. Since $A$. telfairii, which is the type-species of the genus, is genetically closer to $A$. catalai than $A$. monticola, it is the latter that should be placed under a different genus name, 
namely Dajaus which is the earliest genus name available for $A$. monticola (see Table 1 ). The genus Agonostomus under its present, revised definition exclusively occurs in the South-West Indian Ocean [11].

\subsection{Aldrichetta}

Aldrichetta was found it to be the sister subclade of Liza argentea; no taxonomic change is needed for Aldrichetta, which is monotypic [13]. The distribution of this genus is restricted to the temperate coastal waters of Australia and New Zealand [11].

\subsection{Cestraeus}

The genus Cestraeus, represented by two species (C. goldiei and C. oxyrbinchus) in [1] was found to be monophyletic and a brother genus to Chaenomugil, Mugil, and (Agonostomus + Joturus); no taxonomic change is needed regarding Cestraeus because of its monophyly. The genus Cestraeus is present in the Indo-MalayPapua archipelago, in New Caledonia and in Fiji [11].

\subsection{Chaenomugil}

This genus was found to be a brother genus to Cestraeus, Mugil and (Agonostomus + Joturus). No taxonomic change is needed for Chaenomugil, which is monotypic [13]. C. proboscideus, the only species in the genus, occurs in the eastern Pacific, from Baja California to Peru [11].

\subsection{Chelon}

Chelon labrosus grouped with $L$. aurata, L. ramada, L. saliens, L. richardsonii, L. bandialensis, $L$. dumerili, Liza sp. (S. Africa) and L. tricuspidens to form a subclade, which turned out to exclusively comprise species distributed in Atlantic and Mediterranean waters or species apparently endemic to eastern southern Africa (L. tricuspidens and an apparently undescribed Liza sp. [1]). The other Chelon species sampled, all from the Indo-Pacific, formed a distinct subclade together with Indo-Pacific Liza spp. and Paramugil parmatus. All species in the 'Atlantic' subclade (Fig. 5A of [1]), which includes Chelon labrosus (the type species of the genus Chelon) should be placed under Chelon by the principle of priority (see Table 1). The other Liza and Chelon species sampled should be placed under different genera (see below).

\subsection{Crenimugil}

Crenimugil crenilabis (the type species of the genus Crenimugil; Table 1) grouped with Moolgarda seheli and Valamugil buchanani to form a distinct cluster within the (Crenimugil, Moolgarda, Valamugi) subclade. This well-supported lineage should be named Crenimugil because of the priority of the latter to Valamugil (Table 1), and because Moolgarda is both a nomen nudum and a nomen dubium [11]. The close evolutionary affinity of $C$. crenilabis with $M$. seheli and $V$. buchanani has previously been highlighted on the basis of shared morpho-anatomical characters ([10]; Fig. 3). We were unable to obtain a sample of C. heterocheilos, designated by Senou [10] as the type species of his genus Paracrenimugil. Based on the accuracy of the rest of Senou's [10] cladistic tree (Fig. 3), resurrecting the genus Paracrenimugil for C. heterocheilos is an eventuality that deserves consideration. The genus Crenimugil has a wide Indo-West Pacific distribution.

\subsection{Ellochelon}


The genus Ellochelon was found to be the sister lineage of Oedalechilus labiosus. No taxonomic change is needed for Ellochelon, which is monotypic [13]. E. vaigiensis, the only species in the genus, has a wide IndoWest Pacific distribution, from Natal to Tahiti [11].

\subsection{Joturus}

The genus Joturus was the sister lineage of Agonostomus monticola. No taxonomic change is needed for Joturus, which is monotypic [13]. This genus is present on both the Pacific and the Atlantic coasts of the American continent, from Mexico to Panama, and in the Caribbean Sea [11].

\subsection{Liza}

The type species of the genus Liza is Mugil capito (currently L. ramada; [13]). The phylogenetic results of [1] imply that L. ramada be placed under genus Chelon, which in turn implies that Liza is a junior synonym of Chelon. Hence, the name Liza is now unavailable.

Liza argentea and L. falcipinnis were each distinct from the other Liza species, all of which clustered within a single clade (Fig. 2A). The latter comprised Myxus capensis, Oedalechilus labeo, and three subclades: one that corresponds to L. grandisquamis, a second one that includes Chelon labrosus and all Liza spp. of the Atlantic and the Mediterranean (see above), and a third sub-clade that includes Chelon spp. and Liza spp. from the Indo-West Pacific only (namely, C. macrolepis, C. melinopterus, C. planiceps, C. subviridis, L. abu, L. affinis, L. alata, L. haematocheila, and Paramugil parmatus) (Fig. 2A). Liza argentea and L. falcipinnis each merit an individual genus name. Liza argentea was previously assigned to the genus Gracilimugil [36] and we here propose that this genus be resurrected for this species; L. falcipinnis should be assigned a new genus name since there does not seem to be any genus name available for that species (Table 1), and L. grandisquamis should similarly be assigned a new genus name [52]. The 'Indo-West Pacific' (Chelon spp. + Liza spp. $+P$. parmatus) subclade contains $L$. alata, a senior synonym of $L$. ordensis which is the type species of the subgenus Planiliza [37] (Table 1), hence it should be assigned genus name Planiliza by the principle of priority [52]. The genus Gracilimugil occurs in southwestern Australia.

\subsection{Moolgarda}

This genus was polyphyletic (Fig. 1; Fig. 2B). The name Moolgarda predates both Crenimugil and $V$ alamugil (Table 1) but the position of $M$. pura, the type species of the genus [37], is uncertain and the type specimen has been lost [11]. Therefore, Moolgarda should be considered a nomen dubium and no use can be made of this genus name in the present revision. The Moolgarda species that belong to the Crenimugil crenilabis subclade should be placed under Crenimugil (see above). The other species, including M. cunnesius, M. engeli, M. perusii and Valamugil robustus clustered into a distinct subclade (Fig. 2B), hence deserve a different genus name. For this, we propose to use the name Osteomugil following Lüther [42], who described this genus from $M$. cunnesius (the type species), and who also suggested that it might include $M$. engeli.

\subsection{Mugil}

All 9 Mugil species examined by [1] (M. bananensis, M. capurrii, M. cephalus, M. curema, M. hospes, M. incilis, M. liza, M. rubrioculus and M. trichodon) clustered into a single, well-supported clade (Fig. 4A of [1]). Mugil 
was found to be paraphyletic with Xenomugil (Fig. 2C). The name Mugil remains valid by the principle of priority [52] (Table 1). This genus has a temperate-tropical circumglobal distribution [11].

\subsection{Myхus}

Myxus was polyphyletic, with $M$. elongatus (its type-species) pairing with Neomyxus leuciscus, and $M$. capensis being part of the distinct clade external to O. labeo and the two (Liza spp. + Chelon spp.) subclades. The name Myxus should be maintained for M. elongatus (the type-species of the genus), while M. capensis deserves genus rank. As there is currently no genus name available for M. capensis (Table 1), a new genus name has to be proposed. The genus Myxus under its present, revised definition is restricted to the temperate waters of Australia.

\subsection{Neomyxus}

Neomyxus is the sister lineage of M. elongatus. No taxonomic change is needed for Neomyxus, which is monotypic [13]. The only representative of this genus, N. leuciscus, occurs around islands of the Central Pacific, from Hawaii to Samoa [11].

\subsection{Oedalecbilus}

The mitochondrial phylogeny (Fig. 1) revealed a polyphyletic Oedalecbilus: O. labeo, its type species, clustered with Myxus capensis, Chelon spp., Liza spp. and P. parmatus to form a distinct subclade, while $O$. labiosus paired with E. vaigiensis within another subclade that also included R. nasutus. The genus name Oedalechilus should be maintained for O. labeo (its type-species; Table 1), O. labiosus should be reassigned to the genus Plicomugil following Schultz [41] and Harrison and Howes [54]. Therefore, under its present, revised definition, the genus Oedalechilus is monotypic. It occurs in the Western Mediterranean Sea and in the Azores archipelago [11]. The genus Plicomugil is distributed in the Indo-West Pacific, from the Red Sea to the Philippines.

\subsection{Paramugil}

Ghasemzadeh [12] defined the genus Paramugil for P. parmatus, which was embedded within the IndoPacific sub-clade of (Liza spp. + Chelon spp.) (Fig. 2A), for which we argued that the genus name Planiliza be resurrected (see above). Hence, Paramugil should now be regarded as a junior synonym of Planiliza.

\subsection{Rhinomugil}

Rhinomugil was polyphyletic, with R. corsula being the sister lineage of Sicamugil cascasia, while R. nasutus paired with the lineage that includes Ellochelon and O. labiosus (Fig. 1). The name Rhinomugil should be maintained for R. corsula, its type species (Table 1) but R. nasutus should be assigned a different genus name, namely Squalomugil [31] (see Table 1). R. corsula is a freshwater species from India; R. nasutus occurs in the estuarine waters and mangroves of New Guinea and tropical Australia [11].

\subsection{Sicamugil}


Sicamugil was paraphyletic, with S. hamiltonii being sister group to (R. corsula + S. cascasia) (Fig. 1). Sicamugil should be maintained for $S$. hamiltonii, the type species of the genus (Table 1), and S. cascasia should be re-assigned to Senou's [10] Minimugil (Table 1). S. hamiltoni occurs in Myanmar; S. cascasia is distributed in the Ganges River and its tributaries [11].

\subsection{Trachystoma}

Genus Trachystoma formed a distinct clade on its own. The mitochondrial phylogeny confirmed the peculiar systematic status of the monotypic genus Trachystoma (Fig. 1). T. petardi, the only species in the genus, inhabits the rivers of eastern Australia, from Queensland to New South Wales [11].

\subsection{Valamugil}

Most V alamugil species, along with Moolgarda species, were split into two strongly supported lineages, one of which was paraphyletic with Crenimugil crenilabis. V. robustus belonged to another subclade, which also comprised Moolgarda spp. and Valamugil spp. Valamugil should now be considered as a junior synonym of Crenimugil since $V$. seheli (currently Moolgarda seheli), the type species of Valamugil, clusters with $C$. crenilabis (the type species of Crenimugi) into a single, well supported subclade. The subclade that includes M. cunnesius, M. engeli and M. perusii should now be assigned to Lüther's [42] Osteomugil. It is remarkable that Senou's [10] cladistic treatment, based on morphological characters, yielded the same result regarding the Crenimugil / Moolgarda / Valamugil group (Fig. 3) as the present molecular phylogeny (Fig. 2B). Senou [10] however fell short of proposing that $M$. seheli and $V$. buchanani be placed under Crenimugil, and that $M$. cunnesius, M. engeli and M. perusii be placed under Osteomugil. Valamugil robustus was the most externally branching species relative to the other species in our Osteomugil subclade. Therefore, although here we placed $V$. robustus, $M$. cunnesius, $M$. engeli and $M$. perusii under a single genus, it may be argued that $V$. robustus be assigned a different genus name because of the large nucleotide distance that separates it from the other species in the sub-clade. The unique position of the first dorsal fin in $V$. robustus relative to all the other Valamugil spp. and Moolgarda spp. [11] would provide morphological support for this distinction. Nevertheless, we adopted a conservative approach and we leave this taxonomic problem to future research. The genus Osteomugil under its present, revised definition has a wide Indo-Pacific distribution, from South Africa to French Polynesia [11].

\subsection{Xenomugil}

The Xenomugil thoburni haplotypes were found to be embedded within the Mugil curema haplogroup (Fig. 2C). Therefore, there is no phylogenetic rationale to recognizing the genus Xenomugil as valid. The placement of X. thoburni haplotypes within the Mugil spp. subclade implies that Xenomugil is a synonym of Mugil. Further research is needed to clarify the systematics of the $M$. curema species complex and, in particular, whether $X$. thobumi is a distinct, biological species.

\section{Conclusion}

All phylogenetic hypotheses based on morphology and morpho-anatomy proposed within the last few decades for Mugilidae (review in [1]) were in contradiction with one another and the molecular phylogenetic results [1] supported no one. Here, we proposed a new classification that is consistent with 
the molecular phylogeny of [1], resurrecting genus names previously fallen into oblivion and eventually pointing out the need for new genus names in cases where no name is available [52]. The revised classification of the Mugilidae family proposed here recognizes 25 genera, including 15 genera currently considered as valid (Agonostomus, Aldrichetta, Cestraeus, Chaenomugil, Chelon, Crenimugil, Ellochelon, Joturus, Mugil, Myxus, Neomyxus, Oedalecbilus, Rhinomugil, Sicamugil and Trachystoma) and 6 resurrected genera (Gracilimugil, Minimugil, Osteomugil, Planiliza, Plicomugil and Squalomugi). The mitochondrial phylogeny also singled out three isolated lineages (currently L. falcipinnis, Myxus capensis, and L. grandisquamis) for which no genus name is yet available. We here propose the following new genus names: Neochelon gen. nov. (type species: Mugil falcipinnis Valenciennes 1836); Parachelon gen. nov. (type species: M. grandisquamis Valenciennes 1836); and Pseudomyxus gen. nov. (type species: M. capensis Valenciennes 1836). Further genetic evidence is required to confirm or infirm the validity of genus Paracrenimugil proposed by Senou [10] for $C$. heterocheilos, as no genetic data are yet available for this species. Genus names Liza, Moolgarda, Paramugil, Valamugil and Xenomugil were shown to be invalid and they should now be abandoned.

More research is needed to address taxonomic issues at the infra-generic level. For instance, Agonostomus monticola and several species with large distribution ranges (including Moolgarda seheli, Mugil cephalus and M. curema) consisted of separate lineages whose geographic distribution suggests they are cryptic species (Figs. 1, 2). Nuclear-DNA markers are powerful to detect reproductive isolation among cryptic species in sympatry. Nuclear genotyping has already led to identifying three biological species within M. cephalus from Taiwan [55] and two biological species within M. curema from the central western Atlantic [1]. Given the general helplessness of morphology and morpho-anatomy to reconstruct a consistent phylogeny of Mugilidae, a central role should now be assigned to molecular phylogenetics and population genetics in the taxonomy of species in this family.

\section{Taxonomic description of three new mugilid genera}

\subsection{Neochelon, new genus}

The new genus name Neochelon is here proposed for Mugil falcipinnis Valenciennes 1836 [18], here designated as its type species. The nucleotide sequences examined were those of the $y$ tb gene (GENBANK accession no. JQ060212), the COI gene (GENBANK JQ060469), and the 16S rRNA gene (GENBANK JQ060716) of voucher specimen no. MNHN 2009-0730 (from Toubacouta, Saloum estuary, Senegal), and the homologous sequences of specimens collected in St Louis, Senegal (GENBANK JQ060213, JQ060470, and JQ060717; JQ060214, JQ060471, and JQ060718) and at the fish market of Lome, Togo (GENBANK JQ060215, JQ060472, and JQ060719) (Table 1 of [1]). The new genus is unique by the placement of its mitochondrial haplotypes on the phylogenetic tree of Mugilidae (Fig. 1), alone forming one of the seven major clades that stem from the common ancestor to all current mugilid species. The name of the genus is derived from Chelon, preceded by greek prefix "neo-" meaning "new". Distribution: West Africa, from Saint-Louis in northern Senegal to Congo [11].

\subsection{Parachelon, new genus}

The new genus name Parachelon is here proposed for Mugil grandisquamis Valenciennes 1836 [18], here designated as its type species. The nucleotide sequences examined were those of the gytb gene (GENBANK accession nos. JQ060218 and JQ060219), the COI gene (GENBANK JQ060475 and JQ060476), and the 16S rRNA gene (GENBANK JQ060722 and JQ060723) of voucher specimens nos. MNHN 2009-731 and 
SAIAB-83182 (both from Saloum estuary, Senegal), and the homologous sequences of additional specimens collected in the Saloum estuary, Senegal (GENBANK JQ060216, JQ060473, and JQ060720) and at the fish market in Bissau, Guinea Bissau (GENBANK JQ060217, JQ060474, and JQ060721). This new genus is unique by the placement of its mitochondrial haplotypes on the phylogenetic tree of Mugilidae (Fig. 1), where it forms a subclade sister to Chelon, Oedalecbilus, and Planiliza within the clade that also comprises Pseudomyxus gen. nov. The name of the genus is derived from Chelon, preceded by greek prefix "para-" meaning "beside". Distribution: West Africa, from Senegal to Nigeria [11].

\subsection{Pseudomyxus, new genus}

The new genus name Pseudomyxus is here proposed for Mugil capensis Valenciennes 1836 [18], here designated as its type species. The nucleotide sequences examined were those of the cytb gene (GENBANK JQ060366), the COI gene (GENBANK JQ060615) and the 16S rRNA gene (GENBANK JQ060867) of a specimen collected in the East Kleinemonde estuary, South Africa (sampling details in Table 1 of [1]). The new genus is unique by the placement of its mitochondrial haplotypes on the phylogenetic tree of Mugilidae (Fig. 1): Pseudomyxus gen. nov., together with Chelon, Oedalechilus, Parachelon gen. nov. and Planiliza, forms one of the seven major clades of the Mugilidae family. Psendomyxus gen. nov. represents the most external lineage within this clade (Fig. 1). The name of the genus is derived from Myxus, preceded by greek prefix "pseudo-" meaning "false". Distribution: South Africa [11].

\section{Acknowledgements}

We are grateful to T. Ballesteros, S. Banks, F. Bungartz and N. Tirado from the Charles Darwin Foundation for collecting Mugil cephalus and Xenomugil thoburni tissue samples. We thank J.-F. Trape and S. Trape (IRD, Dakar) for stimulating discussions.

\section{References}

[1] J.-D. Durand, K.-N. Shen, W.-J. Chen, B.W. Jamandre, H. Blel, K. Diop, M. Nirchio, F.J. García de León, A.K. Whitfield, C.W. Chang, P. Borsa, Systematics of the Mugilidae (Teleostei: Mugiliformes): Molecular phylogenetic evidence challenges two centuries of morphology-based taxonomy, Mol. Phyl. Evol. 64 (2012) 73-92.

[2] J. Pons, T.G. Barraclough, J. Gomez-Zurita, A. Cardoso, D.P. Duran, S. Hazell, S. Kamoun, W.D. Sumlin, A.P. Vogler, Sequence-based species delimitation for the DNA taxonomy of undescribed insects, Syst. Biol. 55 (2006) 595-609.

[3] M.T. Craig, P.A. Hastings, A molecular phylogeny of the groupers of the subfamily Epinephelinae (Serranidae) with a revised classification of the Epinephelini, Ichthyol. Res. 54 (2007) 1-17.

[4] D.S. Rogers, M.W. González, Phylogenetic relationships among spiny pocket mice (Heteromys) inferred from mitochondrial and nuclear sequence data, J. Mammal. 91 (2010) 914-930.

[5] J.T. Ladner, S.R. Palumbi, Extensive sympatry, cryptic diversity and introgression throughout the geographic distribution of two coral species complexes, Mol. Ecol. 21 (2012) 2224-2238.

[6] D. Tautz, P. Arctander, A. Minelli, R.H. Thomas, A.P. Vogle, A plea for DNA taxonomy, Trends Ecol. Evol. 18 (2003) 70-74.

[7] L. Packer, J. Gibbs, C. Sheffield, R. Hanner, DNA barcoding and the mediocrity of morphology, Mol. Ecol. Resour. 9 (2009) $42-50$.

[8] L.G. Cook, , R.D. Edwards, M.D. Crisp, N.B. Hardy, Need morphology always be required for new species descriptions? Invertebrate Syst. 24 (2010) 322-326.

[9] D. Bickford, D.J. Lohman, N.S. Sodhi, P.K.L. Ng, R. Meier, K. Winker, K.K. Ingram, I. Das, Cryptic species as a window on diversity and conservation, Trends Ecol. Evol. 22 (2007) 148-155.

[10] H. Senou, Phylogenetic interrelationships of the mullets (Pisces: Mugilidae), Ph. D. dissertation, Tokyo University, Tokyo, 1988.

[11] J.M. Thomson, The Mugilidae of the world, Mem. Queensl. Mus. 43 (1997) 457-562.

[12] J. Ghasemzadeh, Phylogeny and systematics of Indo-Pacific mullets (Teleostei: Mugilidae) with special reference to the mullets of Australia, Ph.D. dissertation, Macquarie University, Sydney, 1998. 
[13] W.N. Eschmeyer, R.Fricke (eds.), Catalog of fishes electronic version, 2011 (http://research.calacademy.org/research/ichthyology/catalog/fishcatmain.asp; 5 May 2011).

[14] C. Linnaeus, Systema naturae per regna tria naturae, secundum classes, ordines, genera, species, cum characteribus, differentiis, synonymis, locis, Tomus I, editio decima, reformata, Holmiae, Stockholm, 1758, ii+824 pp.

[15] A.F. Röse, Petri Artedi Angermannia - Sueci synonymia nominum piscium fere omnium; in qua recensio fit nominum piscium, omnium facile authorum, qui umquam de piscibus scripsere: uti graecorum, romanorum, barbarorum; nec non omnium insequentium ichthyologorum, una cum nominibus inquilinis variarum nationum, Ichthyologiae pars IV, editio II, A.F. Röse, Grypeswald (Greifswald), 1793, ii+140 pp.

[16] B.G.E. Lacepède, Histoire naturelle des poissons, tome second, Plassan, Paris, 1799, lxiv+632 pp., 1-20 pls.

[17] E.T. Bennett, Observations on a collection of fishes from Mauritius, presented by Mr. Telfair, with characters of new genera and species, Proc. Gen. Meetings Sci. Business Zool. Soc. Lond. 1830-31 (1832) 165-169.

[18] A. Valenciennes, Livre XIII: Mugiloïdes, In G. Cuvier, A. Valenciennes (eds.), Histoire naturelle des poissons, tome onzième, F.G. Levrault, Paris, 1836, 186 pp.

[19] J. Gistel, Naturgeschichte des Thierreichs für höhere Schulen, Hoffman'sche Verlags-Buchhandlung, Stuttgart, 1848, xvi+216 pp., 32 pls.

[20] F. Poey, Memorias sobre la historia natural de la Isla de Cuba, acompañadas de sumarios latinos y extractos en francés, Tomo 2, Barcina, La Habana, 1861, 442 pp., 19 pls.

[21] A. Günther, Catalogue of the acanthopterygian fishes in the collection of the British Museum, 3. Gobiidae, Discoboli, Pediculati, Blenniidae, Labyrinthici, Mugilidae, Notacanthi, Cat. Fish. Brit. Mus. 3 (1861) i-xxv+1-586+i-x.

[22] T.N. Gill, Descriptive enumeration of a collection of fishes from the western coast of Central America, presented to the Smithsonian Institution by Captain John M. Dow, Proc. Acad. Nat. Sci. Philadelphia 15 (1863) 162-174.

[23] J.D. Macdonald, On the characters of a type of a proposed new genus of Mugilidae inhabiting the fresh waters of Viti Levu, Feejee group; with a brief account of the native mode of capturing it, Proc. Gen. Meetings Sci. Business Zool. Soc. Lond. 1869 (1869) 38-40, 1 pl.

[24] F. Steindachner, Ichthyologische Beiträge (VII), Sitzungsberichte der kaiserlichen Akademie der Wissenschaften, Mathematisch-Naturwissenschaftliche Classe 78 (1878) 377-400.

[25] D.S. Jordan, C.H. Gilbert, List of fishes collected at Panama by Captain John M. Dow, now in the United States National Museum, Proc. U. S. Natl. Mus. 5 (1882) 373-378.

[26] W. Macleay, On a new and remarkable fish of the family Mugilidae from the interior of New Guinea, Proc. Linn. Soc. New South Wales 8 (1883) 2-6.

[27] D.S. Jordan, J. Swain, A review of the American species of marine Mugilidae, Proc. U.S. Natl. Mus. 7 (1884) 261-275.

[28] J.D. Ogilby, On a new genus and species of Australian Mugilidae, Proc. Gen. Meetings Sci. Business Zool. Soc. Lond. 4 (1888) 614-616.

[29] L.L. Vaillant, Sur une collection de poissons recueillie en Basse-Californie et dans le Golfe par M. Léon Diguet, Bull. Soc. Philomatique Paris 6 (1894) 69-75.

[30] H.W. Fowler, New and little known Muglidae and Sphyraenidae, Proc. Acad. Nat. Sci. Philadelphia 55 (1903) 743-752, pls. 45-46.

[31] J.D. Ogilby, New or little known fishes in the Queensland Museum, Ann. Queensl. Mus. 9 (1908) 1-41.

[32] C.T. Regan, A collection of freshwater fishes made by Mr. C. F. Underwood in Costa Rica, Ann. Magazine Nat. Hist. 2 (1908) 455-464.

[33] G.P. Whitley, Five new generic names for Australian fishes, Austr. Zool. 6 (1930) 250-251.

[34] A.M. Popov, Kefali (Mugilidae) ebropi s opisaniem novogo bida iz Tichookeanoskich vod SSSR [Mullets of Europe (Mugilidae) with descriptions of a new species from the Pacific Ocean], Trudy Sevastopol'skoi Biologicheskoi Stantii Akademii nauk SSSR 2 (1930) 47-125.

[35] H.W. Fowler, A small collection of fishes from Rangoon, Burma, Notulae Naturae Acad. Nat. Sci. Philadelphia 17 (1939) 1 12.

[36] G.P. Whitley, Ichthyological notes and illustrations, Austr. Zool. 10 (1941) 1-52.

[37] G.P. Whitley, New sharks and fishes from Western Australia, Part 2, Austr. Zool. 11 (1945) 1-43.

[38] L.P. Schultz, A revision of the genera of mullets, fishes of the family Mugilidae, with descriptions of three new genera, Proc. U.S. Natl. Mus. 96 (1946) 377-395.

[39] G.P. Whitley, New sharks and fishes from Western Australia Part 4, Australian Zoologist 11 (1948) 259-276, pls. 24-25.

[40] J.L.B. Smith, A generic revision of the mugilid fishes of South Africa, Ann. Mag. Nat. Hist. 14 (1948) 833-843.

[41] L.P. Schultz, Family Mugilidae, in L.P. Schultz, E. S. Herald, E.A. Lachner, A.D. Welander, L.P. Woods (eds.), Fishes of the Marshall and Marianas islands, Vol I: Families from Asymmetrontidae through Siganidae, Bull. U.S. Natl Mus. 202 (1953) 310-322.

[42] G. Lüther, New characters for consideration in the taxonomy appraisal of grey mullets, J. Mar. Biol. Ass. India 169 (1982) 1 9.

[43] J. Ghasemzadeh, W. Ivantsoff, Aarn, Historical overview of mugilid systematics, with descriptions of Paramugil (Teleostei: Mugiliformes: Mugilidae), new genus, Aqua J. Ichthyol. Aquat. Biol. 8 (2004) 9-22.

[44] I.J. Harrison, M. Nirchio, C. Oliveira, E. Ron, J. Gaviria, A new species of mullet (Teleostei: Mugilidae) from Venezuela, with a discussion on the taxonomy of Mugil gaimardianus, J. Fish Biol. 71 (Supplement A) (2007) 76-97.

[45] J.S. Nelson, Fishes of the World, John Wiley \& Sons, New York, 2006.

[46] D. Aurelle, R.-M. Barthelemy, J.-P. Quignard, M. Trabelsi, E. Faure, Molecular phylogeny of Mugilidae (Teleostei: Perciformes), Open Mar. Biol. J. 2 (2008) 29-37.

[47] S. Heras, M.I. Roldán, M. Gonzalez Castro, Molecular phylogeny of Mugilidae fishes revised, Rev. Fish Biol. Fisheries 19 (2009) 217-231.

[48] A. Stamatakis, RAxML-VI-HPC: Maximum likelihood-based phylogenetic analyses with thousands of taxa and mixed models, Bioinformatics 22 (2006) 2688-2690. 
[49] K. Tamura, M. Nei, Estimation of the number of nucleotide substitutions in the control region of mitochondrial DNA in humans and chimpanzees, Mol. Biol. Evol. 10 (1993) 512-526.

[50] K. Tamura, D. Peterson, N. Peterson, G. Stecher, M. Nei, S. Kumar, MEGA 5: Molecular evolutionary genetics analysis using maximum likelihood, evolutionary distance, and maximum parsimony methods, Mol. Biol. Evol. 28 (2011) 27312739.

[51] M. Miya, H. Takeshima, H. Endo, N.B. Ishiguro, J.G. Inoue, T. Mukai, T.P. Satoh, M. Yamaguchi, A. Kawaguchi, K. Mabuchi, S.M. Shirai, M. Nishida, Major patterns of higher teleostean phylogenies: a new perspective based on 100 complete mitochondrial DNA sequences, Mol. Phylogenet. Evol. 26 (2003) 121-138.

[52] International Commission on Zoological Nomenclature, International code of zoological nomenclature, 4th edn, International Trust for Zoological Nomenclature, London, 1999, 306 pp.

[53] P.D. Cantino, K. de Queiroz, International code of phylogenetic nomenclature, version 4c, Ohio University, 2010, 102 pp (available from http://www.ohio.edu/PhyloCode/PhyloCode4c.pdf)

[54] I.J. Harrison, G.J. Howes, The pharyngobranchial organ of mugilid fishes; its structure, variability, ontogeny, possible function and taxonomic utility, Bull. Br. Mus. Nat. Hist. (Zool.) 57 (1991) 111-132.

[55] K.-N. Shen, B.W. Jamandre, C.-C. Hsu, W.-N. Tzeng, J.-D. Durand, Plio-Pleistocene sea level and temperature fluctuations in the northwestern Pacific promoted speciation in the globally-distributed flathead mullet Mugil cephalus, BMC Evol. Biol. 11 (2011) 83 . 
Table 1

Nominal genera of the Mugilidae in chronological order of appearance, with their status according to Senou [10], Thomson [11], Ghasemzadeh [12], Eschmeyer and Fricke [13] and this study. ND: no data.

\begin{tabular}{|c|c|c|c|c|c|c|c|c|}
\hline \multirow[t]{2}{*}{ Genus } & \multirow[t]{2}{*}{ Author and date } & \multirow[t]{2}{*}{ Ref. } & \multirow[t]{2}{*}{ Type species } & \multicolumn{5}{|c|}{ Genus assigned by author (date) } \\
\hline & & & & Senou (1988) & Thomson (1997) & $\begin{array}{l}\text { Ghasemzadeh } \\
\text { (1998) }\end{array}$ & $\begin{array}{l}\text { Eschmeyer and } \\
\text { Fricke (2011) }\end{array}$ & This study \\
\hline Mugil & Linnaeus 1758 & {$[14]$} & Mugil cephalus Linnaeus 1758 & Mugil & Mugil & Mugil & Mugil & Mugil \\
\hline Chelon & Artedi 1793 & {$[15]$} & Mugil chelo Cuvier 1829 & Chelon & Chelon & Chelon & Chelon & Chelon \\
\hline Cephalus & Lacepède 1799 & {$[16]$} & Mugil cephalus Linnaeus 1758 & Mugil & Mugil & Mugil & Mugil & Mugil \\
\hline Agonostomus & Bennett 1832 & {$[17]$} & Agonostomus telfairii Bennett 1832 & Agonostomus & Agonostomus & Agonostomus & Agonostomus & Agonostomus \\
\hline Cestraeus & Valenciennes 1836 & {$[18]$} & Cestraeus plicatilis Valenciennes 1836 & Cestraeus & Cestraeus & Cestraeus & Cestraeus & Cestraeus \\
\hline Dajaus & Valenciennes 1836 & {$[18]$} & Mugil monticola Bancroft 1834 & Agonostomus & Agonostomus & Agonostomus & Agonostomus & Dajaus \\
\hline Nestis & Valenciennes 1836 & {$[18]$} & Nestis cyprinoides Valenciennes 1836 & Agonostomus & Agonostomus & Agonostomus & Agonostomus & Agonostomus \\
\hline Arnion & Gistel 1848 & {$[19]$} & Mugil cephalus Linnaeus 1758 & Mugil & Mugil & Mugil & Mugil & Mugil \\
\hline Ello & Gistel 1848 & {$[19]$} & Mugil cephalus Linnaeus 1758 & Mugil & Mugil & Mugil & Mugil & Mugil \\
\hline Joturus & Poey 1860 & {$[20]$} & Joturus pichardi Poey 1860 & Joturus & Joturus & Joturus & Joturus & Joturus \\
\hline Mүхus & Günther 1861 & {$[21]$} & Mvxus elongatus Günther 1861 & Chelon & Mүхus & Mүхus & Mүхus & Mүхus \\
\hline Chaenomugil & Gill 1863 & {$[22]$} & Mugil proboscideus Günther 1861 & Chaenomugil & Chaenomugil & Chaenomugil & Chaenomugil & Chaenomugil \\
\hline Rhinomugil & Gill 1863 & {$[22]$} & Mugil corsula Hamilton 1822 & Rhinomugil & Rhinomugil & Rhinomugil & Rhinomugil & Rhinomugil \\
\hline Gonostomyxus & Macdonald 1869 & {$[23\rceil$} & Gonostomyxus loaloa Macdonald 1869 & Cestraeus & Cestraeus & Cestraeus & Cestraeus & Cestraeus \\
\hline Neomyxus & Steindachner 1878 & {$[24]$} & Myxus (Neomyxus) sclateri Steindachner 1878 & Neomyxus & Chaenomugil & Neomyxus & Neomyxus & Neomyxus \\
\hline Querimana & Jordan and Gilbert 1883 & {$[25]$} & Myxus harengus Günther 1861 & Mugil & Mugil & Mugil & Mugil & Mugil \\
\hline Aeschricbthys & Macleay 1883 & [26] & Aescbrichtbys goldiei Macleay 1883 & Cestraeus & Cestraeus & Cestraeus & Cestraeus & Cestraeus \\
\hline Liza & Jordan and Swain 1884 & $\lceil 27\rceil$ & Mugil capito Cuvier 1829 & Chelon & Liza & Liza & Liza & Chelon \\
\hline Trachystoma & Ogilby 1888 & [28] & Trachystoma multidens Ogilby 1888 & Chelon & Mухи & Trachystoma & Trachystoma & Trachystoma \\
\hline Neomugil & Vaillant 1894 & [29] & Neomugil digueti Vaillant 1894 & Agonostomus & Agonostomus & Agonostomus & Agonostomus & Dajaus \\
\hline Oedalechilus & Fowler 1903 & {$[30]$} & Mugil labeo Cuvier 1829 & Oedalecbilus & Oedalechilus & Oedalecbilus & Oedalechilus & Oedalecbilus \\
\hline Squalomugil & Ogilby 1908 & $\lceil 31\rceil$ & Mugil nasutus de Vis 1883 & Rhinomugil & Rhinomugil & Rhinomugil & Rhinomugil & Squalomugil \\
\hline Xenorbynchichtbys & Regan 1908 & [32] & Joturus stipes Jordan and Gilbert 1882 & Joturus & Joturus & Joturus & Joturus & Joturus \\
\hline Ellochelon & Whitley 1930 & {$[33]$} & Mugil vaigiensis Quoy and Gaimard 1825 & Ellochelon & Liza & Ellochelon & Ellochelon & Ellochelon \\
\hline Protomugil & Popov 1930 & {$[34]$} & Mugil saliens Risso 1810 & Chelon & Liza & Liza & Liza & Chelon \\
\hline Sicamugil & Fowler 1939 & {$[35\rceil$} & Mugil hamiltoni Day 1869 & Sicamugil & Sicamugil & Sicamugil & Sicamugil & Sicamugil \\
\hline Gracilimugil & Whitley 1941 & [36] & Mugil ramsayi Macleay 1883 & Chelon & Liza & Gracilimugil & Liza & Gracilimugil \\
\hline Moolgarda & Whitley 1945 & {$[37]$} & Moolgarda pura Whitley 1945 & Moolgarda & Valamugil & Valamugil & Moolgarda & - \\
\hline Planiliza & Whitley 1945 & {$[37]$} & Moolgarda (Planiliza) ordensis Whitley 1945 & Chelon & Liza & Liza & Liza & Planiliza \\
\hline Aldrichetta & Whitley 1945 & [37ן & Mugil forsteri Valenciennes 1836 & Aldrichetta & Aldrichetta & Aldrichetta & Aldrichetta & Aldrichetta \\
\hline Xenomugil & Schultz 1946 & {$[38]$} & Mugil thoburni Jordan and Starks 1896 & Mugil & Mugil & Mugil & Xenomugil & Mugil \\
\hline Crenimugil & Schultz 1946 & {$[38]$} & Mugil crenilabis Forsskål 1775 & Crenimugil & Crenimugil & Crenimugil & Crenimugil & Crenimugil \\
\hline Heteromugil & Schultz 1946 & {$[38]$} & Mugil tricuspidens Smith 1935 & Chelon & Liza & Liza & Liza & Chelon \\
\hline Oxymugil & Whitley 1948 & $39]$ & Mugil acutus Valenciennes 1836 & Chelon & Liza & Liza & Liza & Planiliza \\
\hline Pteromugil & Smith 1948 & {$[40]$} & Mugil diadema Gilchrist and Thompson 1911 & Chelon & Liza & Liza & Liza & Planiliza \\
\hline Strializa & Smith 1948 & {$[40]$} & Mugil canaliculatus Smith 1935 & Chelon & Liza & Liza & Liza & Chelon \\
\hline$V$ alamugil & Smith 1948 & {$[40]$} & Mugil seheli Forsskål 1775 & Moolgarda & Valamugil & Valamugil & Valamugil & Crenimugil \\
\hline Plicomugil & Schultz 1953 & {$[41]$} & Mugil labiosus Valenciennes 1836 & Oedalecbilus & Oedalecbilus & Oedalechilus & Oedalechilus & Plicomugil \\
\hline Osteomugil & Lüther 1977 & {$[42]$} & Mugil cunnesius Valenciennes 1836 & Moolgarda & Valamugil & Valamugil & Valamugil & Osteomugil \\
\hline Minimugil & Senou 1988 & {$[10]$} & Mugil cascasia Hamilton 1822 & Minimugil & Sicamugil & Sicamugil & Sicamugil & Minimugil \\
\hline Paracrenimugil & Senou 1988 & {$[10]$} & Mugil heterocheilos Bleeker 1855 & Paracrenimugil & Crenimugil & Crenimugil & Crenimugil & ND \\
\hline Psendoliza & Senou 1988 & {$[10]$} & Mugil parmatus Cantator 1849 & Psendoliza & Liza & Paramugil & Paramugil & Planiliza \\
\hline Paramugil & Ghasemzadeh 1998 & {$[12]$} & Mugil parmatus Cantator 1849 & Pseudoliza & Valamugil & Paramugil & Paramugil & Planiliza \\
\hline - & - & - & Mugil falcipinnis Valenciennes 1836 & Chelon & Liza & & Liza & Neochelon gen. nov. \\
\hline - & - & - & Mugil grandisquamis Valenciennes 1836 & Chelon & Lira & Liza & Liza & Parachelon gen. nov. \\
\hline - & - & - & Mugil capensis Valenciennes 1836 & Chelon & Myxus & Myxus & Myxus & Pseudomyxus gen. nov. \\
\hline
\end{tabular}

13 


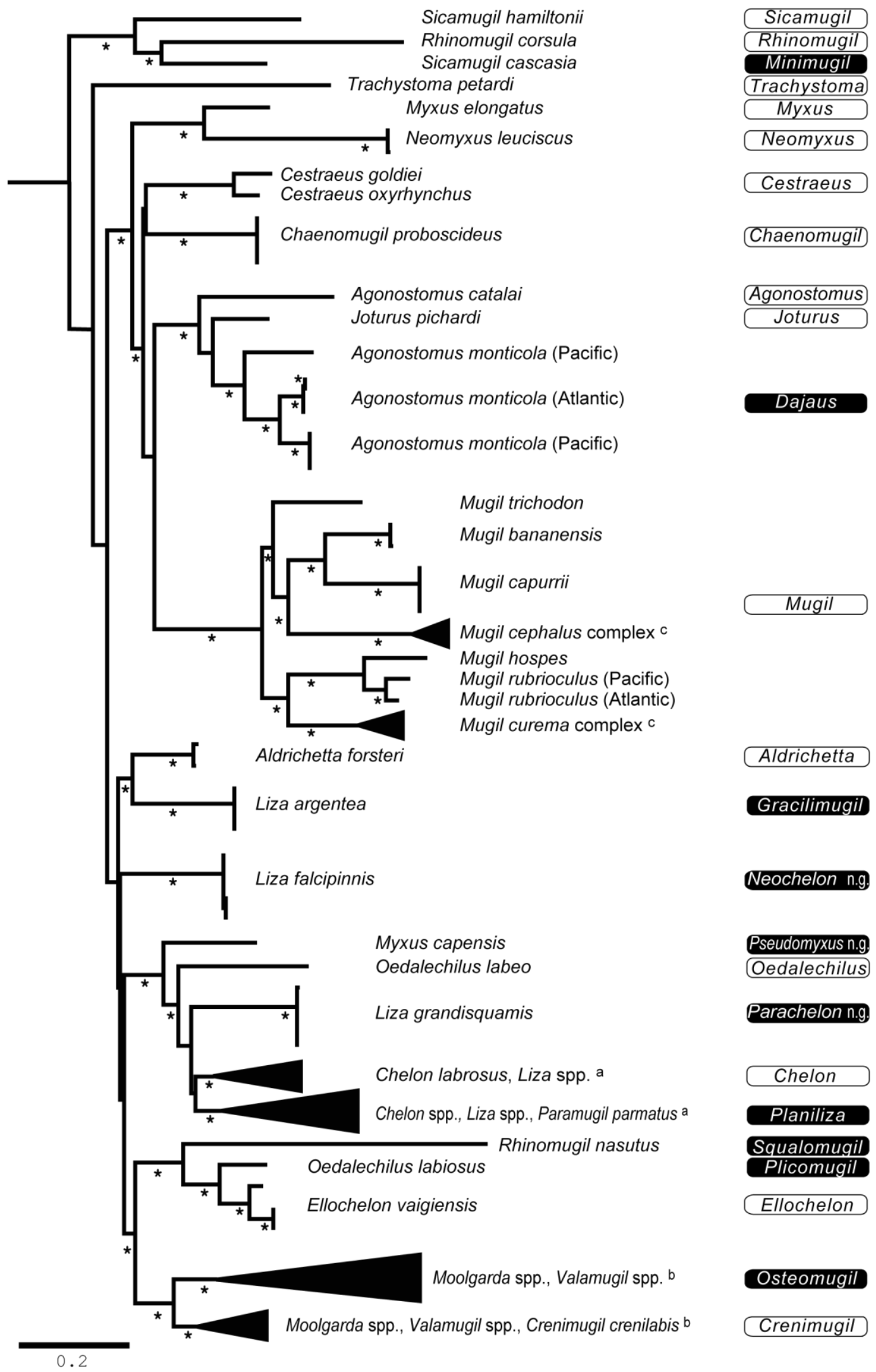

Fig. 1. Revised genus names in Mugilidae, superimposed on the phylogenetic tree of Mugilidae (55 species from 19 genera). inferred using partitioned maximum-likelihood analysis of 3,885 aligned nucleotides from three mitochondrial gene loci (modified from [1]). Taxon names at extremity of branches according to the current nomenclature [13]; when species identification was uncertain, an unknown species or "sp." was assigned to the recognized genus for the taxon. Proposed new genus designations are shown on the right-hand side of the figure; black background: resurrected genera or newly proposed genera ('n. g.'); open: genera maintained in their current name. Asterisks indicate nodes with a posteriori probability from partitioned Bayesian analysis $\geq 0.95$ [1]; scale bar. 0.1 inferred nucleotide substitution/site under (GTR+G+I) model. a Details in Fig. 2A; b details in Fig. 2B; c details in Fig. 2C. 


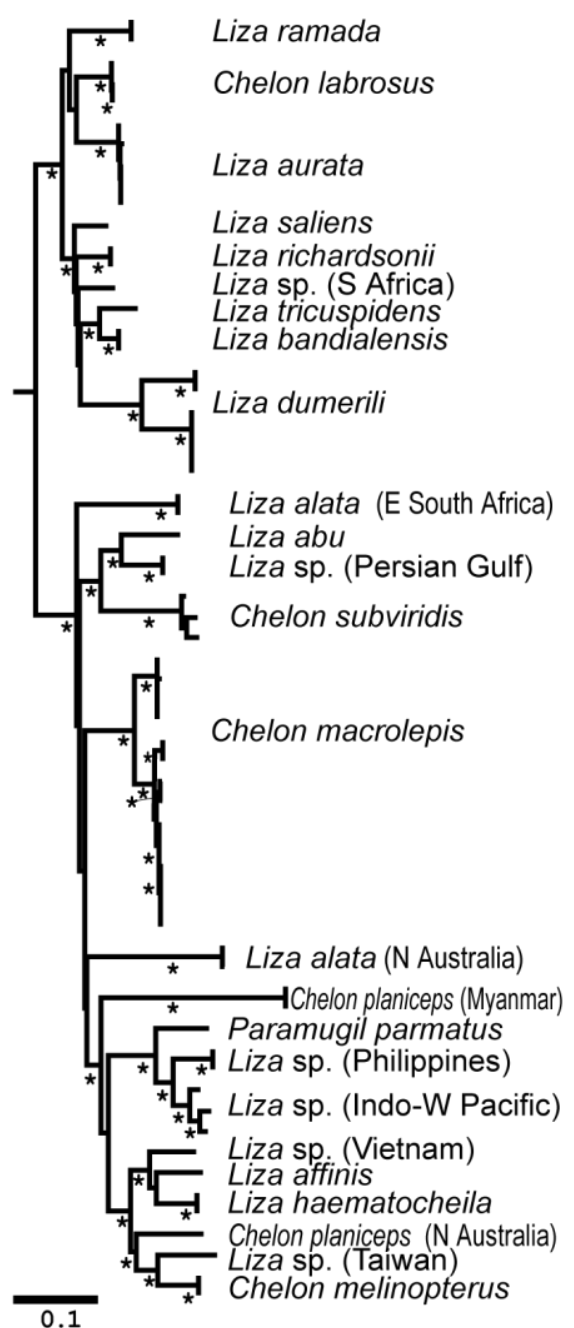

B

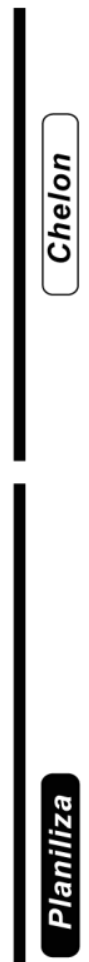

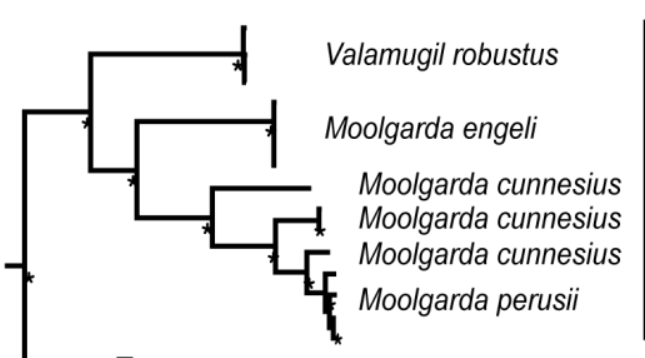

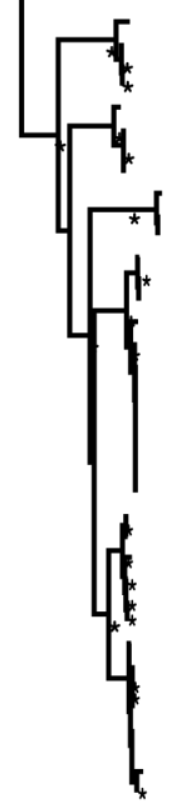

$\overline{0.1}$
Valamugil buchanani

Moolgarda seheli (W Pacific)

Valamugil sp. (W Pacific)

Moolgarda seheli (Indo-W Pacific)

Moolgarda seheli (Indo-W Pacific)

Crenimugil crenilabis

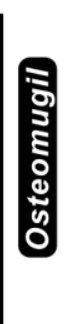

בิ

0.1
Mugil trichodon

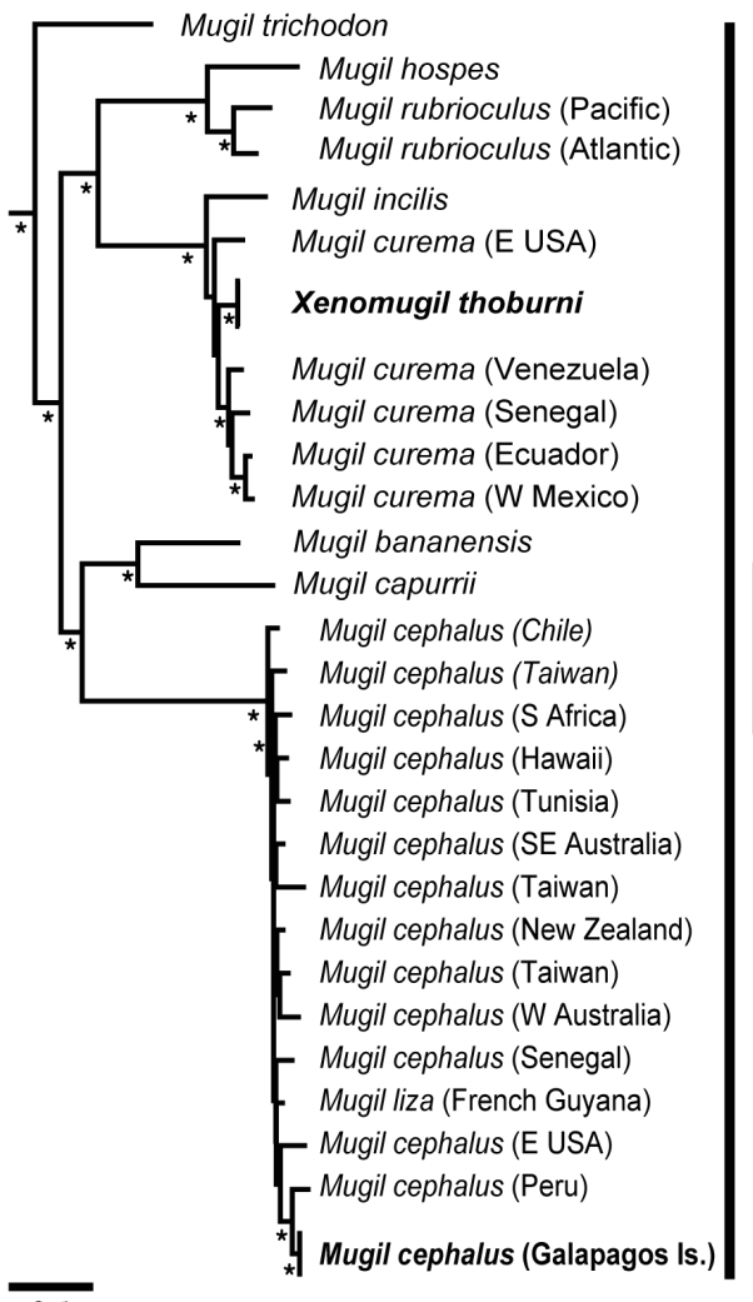

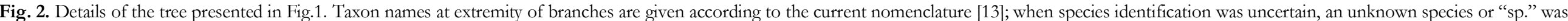

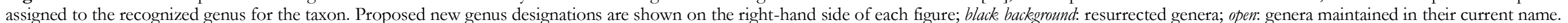

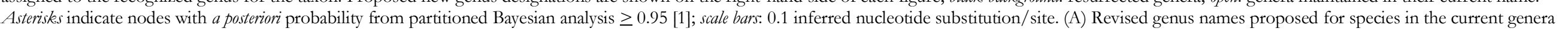

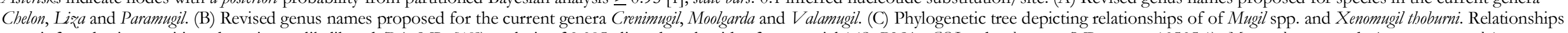

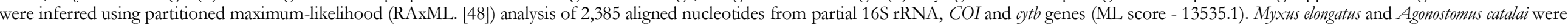
selected as outgroup taxa following the mugilid phylogeny of [1] (Fig.1). Branch lengths are proportional to number of substitutions under the (GTR+G) model. Bold: taxa not included in [1]. 


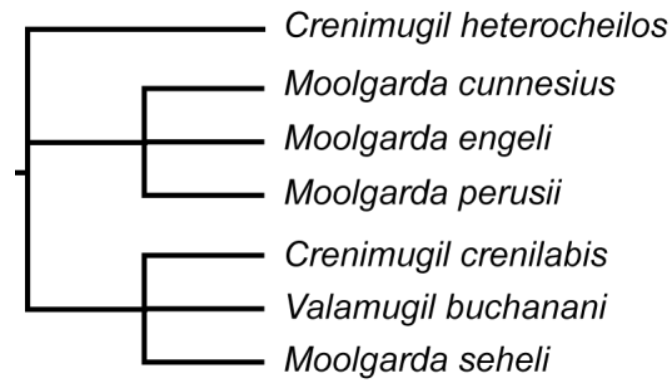

Fig. 3. Parsimony tree of Moolgarda spp., Valamugil buchanani and Crenimugil spp. based on a cladistic analysis of 46 morphological characters (redrawn from [10]). 
A

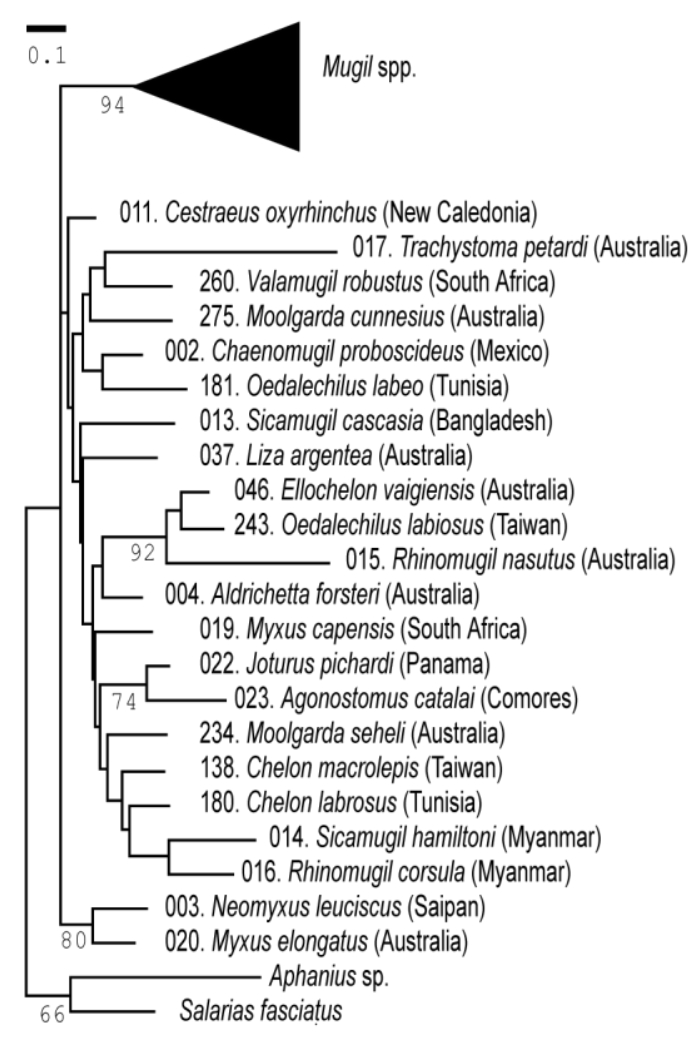

B

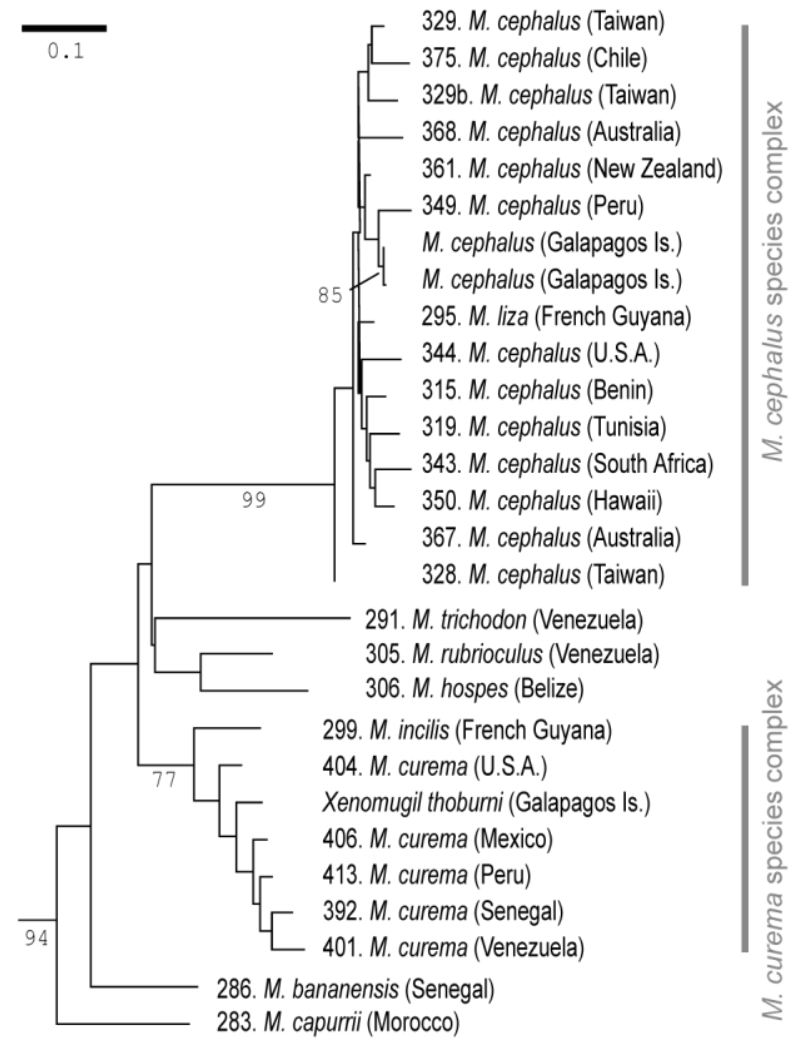

Molecular phylogenetic analysis of Mugilidae partial sequences (300 bp) of the gytb gene, inferred by using the Maximum Likelihood method from Tamura and Nei's [49] model as implemented in MEGA 5 [50]. (A) Entire tree with the highest loglikelihood $[\ln (L)=-5162.2]$. Sequences for outgroups Arcos sp. (Gobiesocidae) and Salarias fasciatus (Blenniidae) [51] are from GENBANK (http://www.ncbi.nlm.nih.gov/; accession nos. AP004452 and AP004451, respectively). (B) Detail of the Mugil subtree; sequences of Xenomugil thoburni and two M. cephalus from the Galapagos Islands were kindly provided by S. Livi (pers. comm.). The percentage of pseudotrees generated by bootstrap resampling (500 runs), in which the associated individuals clustered together is shown next to the branches (bootstrap scores below $70 \%$ not shown). Branch length is proportional to the number of substitutions per site. Specimen numbers refer to Table 1 of [1]. 